\title{
Application of principal component analysis for the optimisation of lead(II) biosorption
}

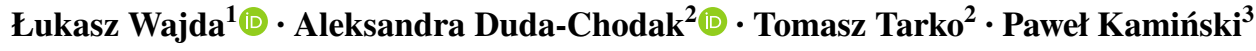

Received: 17 May 2017 / Accepted: 26 September 2017 / Published online: 3 October 2017

(C) The Author(s) 2017. This article is an open access publication

\begin{abstract}
Current study was focused on optimising lead(II) biosorption carried out by living cells of Arthrospira platensis using Principal Component Analysis. Various experimental conditions were considered: initial metal concentration $(50$ and $100 \mathrm{mg} / \mathrm{l})$, solution $\mathrm{pH}(4.0,4.5,5.0,5.5)$ and contact time $(10,20,30,40,50$ and $60 \mathrm{~min})$ at constant rotary speed $200 \mathrm{rpm}$. It was found that when the biomass was separated from experimental solutions by the filtration, almost $50 \%$ of initial metal dose was removed by the filter paper. Moreover, $\mathrm{pH}$ was the most important parameter influencing examined processes. The Principal Component Analysis indicated that the most optimum conditions for lead(II) biosorption were metal initial concentration $100 \mathrm{mg} / \mathrm{l}, \mathrm{pH} 4.5$ and time $60 \mathrm{~min}$. According to the analysis of the first component it might be stated that the lead(II) uptake increases in time. In overall, it was found to be useful for analysing data obtained in biosorption experiments and
\end{abstract}

Łukasz Wajda

1.wajda@uj.edu.pl

Aleksandra Duda-Chodak

a.duda-chodak@ur.krakow.pl

Tomasz Tarko

t.tarko@ur.krakow.pl

Paweł Kamiński

pkamin@agh.edu.pl

1 Malopolska Centre of Biotechnology, Jagiellonian University, Gronostajowa 7A Str, 30-387 Krakow, Poland

2 Department of Fermentation Technology and Technical Microbiology, Faculty of Food Technology, University of Agriculture in Krakow, ul. Balicka 122, 30-149 Krakow, Poland

3 Department of Geomechanics, Civil Engineering and Geotechnics, AGH University of Science and Technology, al. Mickiewicza 30, 30-059 Krakow, Poland eliminating insignificant experimental conditions. Experimental data fitted Langmuir and Dubinin-Radushkevich models indicating that physical and chemical absorption take place at the same time. Further studies are necessary to verify how sorption-desorption cycles affect $A$. platensis cells.

Keywords Arthrospira platensis · Lead · Paper filter . Biosorption · Principal component analysis

\section{Introduction}

Lead is toxic at very low doses and it accumulates in tissues of living organisms. Moreover, this element is the only heavy metal which does not pose any beneficial effects to human body (Damstra 1977). Currently, except from workers employed in industries involving heavy metal processing, children are mostly subjected to lead exposure (Damstra 1977). Therefore, it is necessary to prevent contamination of potable water or food with that element. The group of alternative technologies applied for gaining that goal are based on biosorption-processes involving living or inactivated biomass for heavy metal recovery (Volesky and Naja 2005).

Cyanobacteria belonging to the Arthrospira genus have been tested as biosorbents in various studies (Augusto Da Costa and De França 1998; Gong et al. 2005a; Chen and Pan 2005a, b; Vannela and Verma 2006; Gokhale et al. 2008; Lodi et al. 2008). According to Chen and Pan (2005a) who carried out the research involving living cells of Arthrospira platensis, the biomass removed lead from solutions at concentrations below $10 \mathrm{mg} / \mathrm{l}$. Moreover, in our previous study (Duda-Chodak et al. 2013), we successfully conducted biosorption at higher lead concentrations by engaging immobilised cyanobacterium biomass and at the same time we 
demonstrated that free cells of Arthrospira platensis survived for at least $24 \mathrm{~h}$ in solutions containing up to $100 \mathrm{mg}$ $\mathrm{Pb} / \mathrm{l}$ regardless the $\mathrm{pH}$ of solutions. Therefore, we decided to continue the research involving living cells of $A$. platensis for lead biosorption. We applied Principal Component Analysis (PCA) for analysing that phenomenon and for selecting most optimum parameters of that process.

PCA has been scarcely used for describing biosorption experiments. It has been already applied for optimising bioremediation of dyes used in the food industry with Pittsburgh commercial activated carbon (Al-Degs et al. 2012). It also allowed formulating mathematical model describing those processes. Moreover, the PCA has been applied for optimising the removal of orange 12 dye by activated carbon coated with copper sulfide nanoparticles (Ghaedi et al. 2014). Another research which involved PCA was focusing on soil bioremediation with indigenous microflora but PCA was only used for interpreting patterns obtained by denaturing gradient gel electrophoresis (DGGE), not for describing biosorption processes (Chen et al. 2011). PCA also proved to be very useful tool for analysing metal removal by two species of earthworm and it allowed comparing DNA sequences of those organisms (Dai et al. 2004). It also indicated how each metal influenced Biota-to-Soil accumulation factors.

However, PCA has not been used for optimising heavy metal biosorption so, to the best of our knowledge, current study is the first where that statistical tool was applied. We determined optimum $\mathrm{pH}$, lead initial concentration and contact time of the biosorbent with the solution. Moreover, we discovered that lead is absorbed by filter paper used for separating the cyanobacterium biomass from model solutions.

\section{Materials and methods}

If not stated otherwise, all chemicals used in the study were manufactured by POCh (Gliwice, Poland). Arthrospira platensis (SAG 257.80) was purchased from Sammlung von Algenkulturen Universität Göttingen and cultivated in Zarrouk medium.

\section{Cyanobacterium culture}

The biomass was cultivated at $20 \pm 1{ }^{\circ} \mathrm{C}$ under a fluorescent lamp $40 \mathrm{~W}, 2000-3000 \mathrm{~lx}$ in cycles of $12 \mathrm{~h}$ of light followed by $12 \mathrm{~h}$ of darkness. Cell growth was determined by determining dry matter content (laboratory dryer, $105^{\circ} \mathrm{C}, 2 \mathrm{~h}$ ) which was sufficient for further experiments after approximately 3-4 weeks. Cells were collected by centrifugation $\left(2750 \mathrm{~g}, 20^{\circ} \mathrm{C}\right)$, washed thoroughly with deionized water and centrifuged again under the same conditions. The cell pellet was re-suspended in $25 \mathrm{ml}$ of deionized water and will be further referred to as the 'cell suspension'. The dry matter content of cell suspension was determined each time using a moisture analyser (MAC50, Radwag, Poland).

\section{Biosorption experiments}

Lead solutions (50 or $100 \mathrm{mg} \mathrm{Pb}^{2+} / \mathrm{L}$ ) were prepared using analytical grade lead nitrate $\left[\mathrm{Pb}\left(\mathrm{NO}_{3}\right)_{2}\right]$ and their $\mathrm{pH}(4.0$, $4.5,5.0$, and 5.5) was adjusted with $0.1 \mathrm{M} \mathrm{NaOH}$ or $0.1 \mathrm{M}$ $\mathrm{HCl}$. All glassware was washed with $3 \% \mathrm{HNO}_{3}(12 \mathrm{~h}$ ) before and after each experiment to wash out all potential contaminants. Cell suspension $(1.000 \pm 0.001 \mathrm{~g})$ was introduced into $50 \mathrm{ml}$ of lead solution containing different initial metal dose (50 or $100 \mathrm{mg} \mathrm{Pb} / \mathrm{L}$ ) and holding various initial $\mathrm{pH}$ (4.0, 4.5, 5.0, and 5.5). Then samples were incubated with continuous shaking $(200 \mathrm{rpm})$ at room temperature. Cyanobacterium cells were removed from solutions by filtration (filter paper, grade $3 \mathrm{~m} / \mathrm{N}$, diameter $110 \mathrm{~mm}$, Munktell, Sweden) after 10, $20,30,40,50$, or $60 \mathrm{~min}$.

Obtained filtrates were adjusted to $\mathrm{pH} 2$ with $1 \mathrm{M}$ nitric(V) acid and lead concentration was determined by atomic absorption spectrophotometry (AAS) (Varian AA 240 FS, Varian Inc. Agilent Technologies). In the case of control samples (lead solutions without cell suspension) filter paper disks were mineralized after estimated time with concentrated nitric(V) acid (MARSXpress Microwave Digestion System, Warszawa Poland) at $170{ }^{\circ} \mathrm{C}$ for $15 \mathrm{~min}$. The quantity of metal absorbed by the filter was determined as in the case of liquid samples. All experiments were performed at least in three replicates.

\section{Sorption isotherms}

The lead uptake $(q)$ of cyanobacterium biomass was calculated twice. Firstly, the following mass balance equation (Eq. 1) for the biosorbent was used (Volesky 2004):

$q=\frac{\left[V \times\left(C_{0}-C_{f}\right)\right]}{S}$

For the second time, the corrected equation (Eq. 2) which considers the quantity of lead absorbed by the filter paper was used:

$q_{\text {corr }}=\frac{\left[V \times\left(C_{i}-C_{f}\right)\right]}{S}$

In both equations, the following symbols were used: $q$-lead uptake at equilibrium ( $\mathrm{mg} \mathrm{Pb} / \mathrm{g}$ biosorbent dry matter); $V$-volume of metal-bearing solution (1); $C_{0}$-initial lead concentration $(\mathrm{mg} / \mathrm{l}) ; \mathrm{Ci}$-corrected lead concentration after subtracting the quantity of the metal absorbed by the paper filter $(\mathrm{mg} / \mathrm{l}) ; C_{f}$ - final lead concentration $(\mathrm{mg} / \mathrm{l}) ; S$ dry matter of the biosorbent $(\mathrm{g})$. 
Langmuir isotherm was based on the following equation (Eq. 3):

$q_{\text {corr }}=\frac{\left(Q_{\max } \times b \times C_{i}\right)}{\left(1+b \times C_{i}\right)}$

$Q_{\max }$ and $b$ are Langmuir constants indicating maximum sorption capacities (mg/mg of dry matter) and sorbent/ sorbate affinity, respectively (Volesky 2004) while $q_{e}$ is the amount of metal adsorbed at equilibrium. Both constants were calculated by plotting $1 / q_{\text {corr }}$ versus $1 / C_{i}$ and adding trend line. Then $Q_{\max }$ and $b$ were obtained as follows: slope $=1 /\left(Q_{\max } \cdot b\right)$ and intercept $=1 / b$. Langmuir isotherm was obtained by plotting $C_{i} / q_{\text {corr }}$ versus $C_{i}$.

Linearised form of Freundlich model applied in the current study was as follows (Eq. 4):

$q_{\text {corr }}=k \times C_{i}^{1 / n}$

where $k$ and $n$ are Freundlich constants were obtained by plotting $\log \left(q_{\text {corr }}\right)$ versus $\log \left(C_{i}\right)$ while $q_{e}$ is the amount of metal adsorbed at equilibrium. Constants were calculated according to Volesky (2004).

Another biosorption isotherm which was examined in the current study was Dubinin-Radushkevich isotherm (Dada et al. 2012) (Eq. 5):

$\ln q_{\text {corr }}=\ln q_{s}-K_{a d} \times \varepsilon^{2}$

where $\mathrm{q}_{\mathrm{s}}$ is the theoretical isotherm saturation capacity (mg $\left.\mathrm{Pb}^{2+} / \mathrm{g}\right), \mathrm{K}_{\mathrm{ad}}$ is Dubinin-Radushkevich isotherm constant $\left(\mathrm{mol}^{2} / \mathrm{kJ}^{2}\right)$. Mean free energy of metal ions (E) was obtained from the Eq. (6) following equation where $B_{D R}$ is the isotherm constant:

$E=\frac{1}{\sqrt{2 \times B_{D R}}}$

While $\varepsilon$ constant was obtained in Eq. (7):

$\varepsilon=R T\left(1+\frac{1}{C_{f}}\right)$

$\mathrm{R}$ is the gas constant $(8.314 \mathrm{~J} / \mathrm{mol} \mathrm{K})$ and $\mathrm{T}$ is the absolute temperature $(301.15 \mathrm{~K})$. Isotherm parameters were calculated from the slope $\left(\mathrm{K}_{\mathrm{ad}}\right)$ of the plot of $\operatorname{lnq}_{\mathrm{cor}}$ versus $\varepsilon^{2}$ and the exponent calculated from the intercept of the plot gave $\mathrm{q}_{\mathrm{m}}$ (Erhayem et al. 2015).

Lagergren pseudo-first (Eq. 8) and pseudo-second (Eq. 9) order equations were applied for estimating kinetic models as in Erhayem et al. (2015):

$\log \left(q_{e}-q_{t}\right)=\log q_{e}-\left(\frac{k_{1}}{2.303}\right) t$ $\frac{t}{q_{t}}=\frac{1}{k_{2} q_{2}^{2}}+\frac{t}{q_{2}} t$

Symbols used in the equations demonstrated above were: $\mathrm{q}_{\mathrm{e}}$ - the adsorption equilibrium capacity $(\mathrm{mg} / \mathrm{g}), \mathrm{q}_{\mathrm{t}}$ - the quantity of lead(II) adsorbed (mg/g) at time $\mathrm{t}, \mathrm{k}_{1}$ - the rate constant of pseudo-first-order $\left(\mathrm{min}^{-1}\right), \mathrm{q}_{2}$ - the maximum adsorption capacity $(\mathrm{mg} / \mathrm{g})$ and $\mathrm{k}_{2}$ - the rate constant of pseudo-second-order $(\mathrm{g} / \mathrm{mg} \cdot \mathrm{min})$. Constants $\left(\mathrm{k}_{1}, \mathrm{k}_{2}\right.$ and $\left.\mathrm{q}_{2}\right)$ were obtained from slope and intercept of pseudo-first-order and pseudo-second-order plots between $\log \left(\mathrm{q}_{\mathrm{e}}-\mathrm{q}_{\mathrm{t}}\right)$ versus $t$ and $t / q_{t}$ versus $t$.

\section{Statistical analysis}

All experiments were carried out at least in triplicates. The results are shown as arithmetic means ( \pm standard deviation). The normality of distribution was assessed by Shapiro-Wilk test and significance of differences between means was assessed by one-way variance analysis (ANOVA) with post hoc Tukey test. The Principal Component Analysis (PCA) with varimax rotation was applied to assess correlations among variables. All statistical analyses were carried out using R: A language and environment for statistical computing, version 3.1.3 (Foundation for Statistical Computing, Vienna, Austria, 2015). ANOVA was carried out using "Im" function and Tukey test was done using "HSD.test" function in the "agricolae" package. The PCA was carried out in "psych" package (Beaumont 2012). Cortest-Bartlett test was carried out using "cortest.bartlett" function in "psych" package as well. The data demonstrated normal distribution so its transformation was not necessary. Strong correlations between loads and scores were considered when values obtained in correlation matrix exceeded 0.3 .

\section{Results}

It seems that $\mathrm{pH} 4.0$ was optimum when lead initial concentration $50 \mathrm{mg} / \mathrm{l}$, while $\mathrm{pH} 4.5$ supported metal recovery at $100 \mathrm{mg} / \mathrm{l}$ (Tables 1,2). Equilibrium was reached after $40 \mathrm{~min}$ at most of cases. At both initial lead concentrations, the quantity of metal adsorbed by paper disks did not exceed half of its initial quantity in experimental solutions (Tables 1,2). Due to that fact, all q values were recalculated according to the Eq. (2) and it appears that the efficiency of lead removal did not exceed $70 \%$, while it was approximately $90 \%$ before implementing corrections to the Eq. (1) (Tables 1, 2).

Principal Component Analysis of lead(II) uptake was carried out only for results obtained from the Eq. (2). Scripts prepared by Beaumont (2012) were applied for all calculations. Different $\mathrm{pH}$ values were considered as loadings and 
Table 1 The comparison of lead uptake (q) by A. platensis at $\mathrm{Pb}^{2+}$ initial concentration $50 \mathrm{mg} / \mathrm{l}$ calculated per Eqs. $(1,2)$

\begin{tabular}{|c|c|c|c|c|c|}
\hline $\mathrm{pH}$ & $\begin{array}{l}\text { Contact time } \\
\text { [min] }\end{array}$ & $\begin{array}{l}\text { Corrected lead } \\
\text { concentration } \\
\mathrm{C}_{\mathrm{i}}[\mathrm{mg} / \mathrm{l}]\end{array}$ & $\begin{array}{l}\text { Final lead con- } \\
\text { centration } \\
\mathrm{C}_{\mathrm{f}}[\mathrm{mg} / \mathrm{l}]\end{array}$ & $\begin{array}{l}\text { Lead uptake } \\
\text { q (Eq. 1) } \\
\text { [mg/g d.m.] }\end{array}$ & $\begin{array}{l}\text { Corrected lead uptake } \\
\left.\mathrm{q}_{\text {corr }} \text { (Eq. } 2\right) \\
\text { [mg/g d.m.] }\end{array}$ \\
\hline \multirow[t]{6}{*}{4.0} & 10 & \multirow[t]{6}{*}{26.76} & $14.30 \pm 1.43$ & $54.09 \pm 1.94^{b}$ & $18.9 \pm 4.1^{\mathrm{b}}$ \\
\hline & 20 & & $9.62 \pm 0.96$ & $61.19 \pm 1.32^{\mathrm{b}}$ & $26.0 \pm 6.7^{b}$ \\
\hline & 30 & & $6.93 \pm 0.69$ & $65.26 \pm 0.92^{\mathrm{b}}$ & $30.0 \pm 6.5^{\mathrm{b}}$ \\
\hline & 40 & & $9.52 \pm 0.95$ & $134.93 \pm 2.88^{\mathrm{a}}$ & $57.5 \pm 4.9^{\mathrm{a}}$ \\
\hline & 50 & & $10.56 \pm 1.06$ & $131.46 \pm 3.11^{\mathrm{a}}$ & $54.0 \pm 8.8^{\mathrm{a}}$ \\
\hline & 60 & & $10.67 \pm 1.07$ & $131.10 \pm 3.13^{\mathrm{a}}$ & $53.6 \pm 3.3^{\mathrm{c}, \mathrm{d}}$ \\
\hline \multirow[t]{6}{*}{4.5} & 10 & \multirow[t]{6}{*}{18.52} & $16.53 \pm 1.65$ & $79.69 \pm 3.52^{\mathrm{c}, \mathrm{d}}$ & $4.7 \pm 2.4^{\mathrm{d}}$ \\
\hline & 20 & & $17.94 \pm 1.79$ & $76.33 \pm 3.23^{\mathrm{d}}$ & $1.4 \pm 0.0^{\mathrm{d}}$ \\
\hline & 30 & & $16.46 \pm 1.65$ & $79.86 \pm 3.51^{\mathrm{b}, \mathrm{c}, \mathrm{d}}$ & $4.9 \pm 3.6^{\mathrm{b}, \mathrm{c}, \mathrm{d}}$ \\
\hline & 40 & & $12.86 \pm 1.29$ & $88.43 \pm 2.80^{\mathrm{a}}$ & $13.5 \pm 1.6^{\mathrm{a}}$ \\
\hline & 50 & & $14.71 \pm 1.47$ & $84.02 \pm 3.09^{\mathrm{a}, \mathrm{b}, \mathrm{c}}$ & $9.1 \pm 1.6^{\text {a,b.c }}$ \\
\hline & 60 & & $13.50 \pm 1.35$ & $86.90 \pm 2.82^{\mathrm{a}, \mathrm{b}}$ & $11.9 \pm 3.8^{\mathrm{a}, \mathrm{b}}$ \\
\hline \multirow[t]{6}{*}{5.0} & 10 & \multirow[t]{6}{*}{21.12} & $7.36 \pm 0.74$ & $152.29 \pm 2.40^{\mathrm{a}}$ & $49.1 \pm 1.1^{\mathrm{a}}$ \\
\hline & 20 & & $19.80 \pm 1.98$ & $107.85 \pm 6.39^{\mathrm{b}}$ & $7.3 \pm 3.5^{\mathrm{b}}$ \\
\hline & 30 & & $19.94 \pm 1.99$ & $107.36 \pm 6.39^{b}$ & $6.3 \pm 4.3^{\mathrm{b}}$ \\
\hline & 40 & & $14.75 \pm 1.47$ & $125.89 \pm 4.63^{b}$ & $22.8 \pm 3.5^{\mathrm{b}}$ \\
\hline & 50 & & $19.19 \pm 1.92$ & $110.04 \pm 6.23^{b}$ & $6.9 \pm 5.4^{\mathrm{b}}$ \\
\hline & 60 & & $17.69 \pm 1.77$ & $115.39 \pm 5.59^{b}$ & $12.2 \pm 5.4^{\mathrm{b}}$ \\
\hline \multirow[t]{6}{*}{5.5} & 10 & \multirow[t]{6}{*}{14.03} & $12.90 \pm 1.29$ & $92.75 \pm 2.91^{\mathrm{b}}$ & $2.8 \pm 0.0^{\mathrm{b}}$ \\
\hline & 20 & & $4.35 \pm 0.43$ & $114.13 \pm 0.92^{\mathrm{a}}$ & $24.2 \pm 1.2^{\mathrm{a}}$ \\
\hline & 30 & & $5.94 \pm 0.59$ & $110.15 \pm 1.23^{\mathrm{a}}$ & $20.3 \pm 0.9^{a}$ \\
\hline & 40 & & $7.73 \pm 0.77$ & $105.68 \pm 1.79^{\mathrm{a}}$ & $15.8 \pm 1.4^{\mathrm{a}}$ \\
\hline & 50 & & $9.06 \pm 0.91$ & $102.35 \pm 1.90^{\mathrm{a}, \mathrm{b}}$ & $12.4 \pm 7.0^{\mathrm{a}, \mathrm{b}}$ \\
\hline & 60 & & $8.88 \pm 0.89$ & $102.80 \pm 2.01^{\mathrm{a}, \mathrm{b}}$ & $12.9 \pm 3.3^{\mathrm{a}, \mathrm{b}}$ \\
\hline
\end{tabular}

a,b,c The same letters next to values of lead uptake calculated according to the Eq. (1) or Eq. (2) at certain $\mathrm{pH}$ value (column) indicate the lack of statistically significant differences between means $(\mathrm{p}<0.05), \mathrm{n}=6$ lead uptake values $\left(\mathrm{q}_{\text {corr }}\right)$ obtained at different time intervals and two different lead initial concentrations (50 and $100 \mathrm{mg} / \mathrm{l}$ ) were considered as scores (samples). Correlation matrix (Table 3) showed significant dependencies among considered components (correlation factors above 0.3 ) that formed two clusters. The $\mathrm{p}$ value obtained in Cortest-Bartlett test was relatively low (0.00004), yet it allowed continuing the analysis. In case of both initial lead concentrations it was shown that the first three components explained over $95 \%$ variance which indicates that $\mathrm{pH} 5.5$ is not significant for lead biosorption carried out by A. platensis so this value could be omitted in further experiments. The strongest correlation $(\mathrm{r}=0.8990)$ was found between $\mathrm{pH} 4.5$ and $\mathrm{pH} 5.5$ (Fig. 1).

It was also indicated that $\mathrm{q}_{\text {corr }}$ values obtained after 20 , 30 and 40 min contact time are correlated with $\mathrm{pH} 4.5$ when initial metal concentration was $100 \mathrm{mg} / \mathrm{l}$ (Fig. 1). Another conclusion is that $\mathrm{Pb}^{2+}$ recovery at $100 \mathrm{mg} / \mathrm{l}$ is correlated with $\mathrm{pH}$ values 4.0, 4.5 and 5.5. Moreover, it was found that shaking time is less significant factor in biosorption phenomenon. The optimum parameters for lead(II) biosorption carried out by A. platensis are $\mathrm{pH} 4.5$, initial $\mathrm{Pb}^{2+}$ concentration $100 \mathrm{mg} / \mathrm{l}$ and shaking time $60 \mathrm{~min}$.

The first principal component was strongly correlated with five of the original variables at lead initial concentration $100 \mathrm{mg} / \mathrm{ml}$ : 10, 20, 30, 40 and $60 \mathrm{~min}$ (Table 4). This suggests that the lead uptake increases in time of the process. Furthermore, the first principal component correlates most strongly with the time 30 min which suggests that it has got the most significant impact on lead biosorption. It might be also stated that metal biosorption reaches equilibrium after $40 \mathrm{~min}$. The third principal component influences more variables, however, that influence is much weaker since it explains $28.6 \%$ of the variance while the first principal component explains $41.7 \%$ of the variance. Nevertheless, based on values obtained for the third component it might be stated that the equilibrium of lead(II) biosorption is reached within $30 \mathrm{~min}$ at metal initial concentration $50 \mathrm{mg} / \mathrm{l}$. Another conclusion obtained from analysing the third component is that at lead initial concentration $100 \mathrm{mg} / \mathrm{l}$ maximum metal uptake was reached after $50 \mathrm{~min}$ (the highest principal component value 1.2829 , Table 4 ). 
Table 2 The comparison of lead uptake (q) by A. platensis at $\mathrm{Pb}^{2+}$ initial concentration $100 \mathrm{mg} / \mathrm{l}$ calculated per Eqs. $(1,2)$

\begin{tabular}{|c|c|c|c|c|c|}
\hline $\mathrm{pH}$ & $\begin{array}{l}\text { Contact time } \\
\text { [min] }\end{array}$ & $\begin{array}{l}\text { Corrected lead } \\
\text { concentration } \\
\mathrm{C}_{\mathrm{i}}[\mathrm{mg} / \mathrm{l}]\end{array}$ & $\begin{array}{l}\text { Final lead concentration } \\
\mathrm{C}_{\mathrm{f}}[\mathrm{mg} / \mathrm{l}]\end{array}$ & $\begin{array}{l}\text { Lead uptake } \\
\text { q (Eq. 1) } \\
\text { [mg/g d.m.] }\end{array}$ & $\begin{array}{l}\text { Corrected lead uptake } \\
\left.\mathrm{q}_{\text {corr }} \text { (Eq. } 2\right) \\
\text { [mg/g d.m.] }\end{array}$ \\
\hline \multirow[t]{6}{*}{4.0} & 10 & \multirow[t]{6}{*}{68.38} & $35.42 \pm 3.54$ & $111.35 \pm 5.40^{\mathrm{c}}$ & $56.8 \pm 6.4^{\mathrm{c}}$ \\
\hline & 20 & & $33.89 \pm 3.39$ & $113.98 \pm 5.25^{\mathrm{c}}$ & $59.5 \pm 13.3^{\mathrm{c}}$ \\
\hline & 30 & & $31.10 \pm 3.11$ & $118.79 \pm 4.98^{\text {b.c }}$ & $64.3 \pm 6.1^{\mathrm{b}, \mathrm{c}}$ \\
\hline & 40 & & $23.58 \pm 2.36$ & $131.76 \pm 2.56^{\mathrm{a}}$ & $77.2 \pm 4.1^{\mathrm{a}}$ \\
\hline & 50 & & $21.90 \pm 2.19$ & $134.66 \pm 2.59^{\mathrm{a}}$ & $80.1 \pm 4.2^{\mathrm{a}}$ \\
\hline & 60 & & $25.38 \pm 2.54$ & $128.66 \pm 3.46^{\mathrm{a}, \mathrm{b}}$ & $74.1 \pm 2.5^{\mathrm{a}, \mathrm{b}}$ \\
\hline \multirow[t]{6}{*}{4.5} & 10 & \multirow[t]{6}{*}{64.77} & $34.14 \pm 3.41$ & $173.16 \pm 5.72^{\mathrm{d}}$ & $80.6 \pm 12.4^{\mathrm{d}}$ \\
\hline & 20 & & $29.53 \pm 2.95$ & $185.45 \pm 3.59^{\mathrm{b}, \mathrm{c}}$ & $92.7 \pm 9.8^{\mathrm{b}, \mathrm{c}}$ \\
\hline & 30 & & $29.33 \pm 2.93$ & $185.97 \pm 5.49^{\mathrm{b}, \mathrm{c}}$ & $93.3 \pm 9.9^{\mathrm{b}, \mathrm{c}}$ \\
\hline & 40 & & $31.33 \pm 3.13$ & $180.71 \pm 6.06^{\mathrm{c}, \mathrm{d}}$ & $88.0 \pm 9.2^{\mathrm{b}, \mathrm{c}, \mathrm{d}}$ \\
\hline & 50 & & $26.15 \pm 2.61$ & $194.34 \pm 5.00^{\mathrm{a}, \mathrm{b}}$ & $101.6 \pm 8.1^{\mathrm{a}, \mathrm{b}}$ \\
\hline & 60 & & $23.25 \pm 2.32$ & $201.97 \pm 4.91^{\mathrm{a}}$ & $109.3 \pm 9.8^{\mathrm{a}}$ \\
\hline \multirow[t]{6}{*}{5.0} & 10 & \multirow[t]{6}{*}{41.43} & $30.15 \pm 3.01$ & $183.82 \pm 5.75^{\mathrm{a}, \mathrm{b}}$ & $29.7 \pm 4.3^{\mathrm{a}, \mathrm{b}}$ \\
\hline & 20 & & $31.89 \pm 3.12$ & $179.24 \pm 6.26^{\mathrm{b}}$ & $25.1 \pm 19.1^{\mathrm{b}}$ \\
\hline & 30 & & $31.21 \pm 3.12$ & $181.03 \pm 5.08^{b}$ & $26.9 \pm 14.3^{\mathrm{b}}$ \\
\hline & 40 & & $26.36 \pm 2.36$ & $193.78 \pm 5.47^{\mathrm{a}}$ & $39.7 \pm 6.7^{\mathrm{a}}$ \\
\hline & 50 & & $26.24 \pm 2.62$ & $194.10 \pm 5.05^{\mathrm{a}}$ & $40.0 \pm 5.7^{\mathrm{a}}$ \\
\hline & 60 & & $27.43 \pm 2.74$ & $190.97 \pm 8.28^{\mathrm{a}, \mathrm{b}}$ & $36.8 \pm 4.5^{\mathrm{a}, \mathrm{b}}$ \\
\hline \multirow[t]{6}{*}{5.5} & 10 & \multirow[t]{6}{*}{53.06} & $31.47 \pm 3.15$ & $131.79 \pm 4.11^{\mathrm{b}}$ & $41.5 \pm 14.9^{b}$ \\
\hline & 20 & & $28.98 \pm 2.90$ & $136.58 \pm 4.66^{\mathrm{b}}$ & $46.3 \pm 11.6^{\mathrm{a}}$ \\
\hline & 30 & & $26.67 \pm 2.67$ & $141.02 \pm 3.32^{\mathrm{a}, \mathrm{b}}$ & $50.8 \pm 0.6^{\mathrm{a}, \mathrm{b}}$ \\
\hline & 40 & & $21.93 \pm 2.19$ & $150.14 \pm 3.45^{\mathrm{a}}$ & $59.9 \pm 23.4^{\mathrm{b}}$ \\
\hline & 50 & & $31.48 \pm 3.15$ & $131.76 \pm 2.98^{b}$ & $41.5 \pm 18.3^{\mathrm{a}, \mathrm{b}}$ \\
\hline & 60 & & $30.30 \pm 3.03$ & $134.04 \pm 3.91^{b}$ & $43.8 \pm 7.5^{\mathrm{b}}$ \\
\hline
\end{tabular}

a,b,c The same letters next to values of lead uptake calculated according to the Eq. (1) or Eq. (2) at certain $\mathrm{pH}$ value (column) indicate the lack of statistically significant differences between means $(\mathrm{p}<0.05), \mathrm{n}=6$
Table 3 Correlation matrix for lead initial concentrations 50 and $100 \mathrm{mg} / \mathrm{l}$

\begin{tabular}{lllll}
\hline & $\mathrm{pH} 4.0$ & $\mathrm{pH} 4.5$ & $\mathrm{pH} \mathrm{5.0}$ & $\mathrm{pH} \mathrm{5.5}$ \\
\hline pH 4.0 & 1.0000 & & & \\
pH 4.5 & 0.8055 & 1.0000 & & \\
pH 5.0 & 0.3671 & 0.5760 & 1.0000 & \\
pH 5.5 & 0.7229 & 0.8990 & 0.3605 & 1.0000 \\
\hline
\end{tabular}

Squares indicate clusters of correlated data

Freundlich model verifies if the biosorbent surface is homogenous while Langmuir isotherm allows determining the affinity of metal ions to the biosorbent and estimating the number of binding sites (Volesky 2004). Dubinin-Raduskhevich model is used for estimating material porosity and the apparent energy of adsorption (Hutson and Yang 1997). Freundlich, Lngmuir and Dubinin-Radushkevich isotherms were plotted for $\mathrm{q}_{\text {corr }}$ obtained at different time intervals at $\mathrm{pH} 4.5$ and lead(II) initial concentration $100 \mathrm{mg} / \mathrm{l}$ (Figs. 2, 3, 4) since those conditions were indicated by the PCA as the most optimum for the biosorption process. The experimental data fitted best Langmuir and Dubinin-Radushkevich models (Table 5). In the case of pseudo-first kinetic model it was demonstrated that biosorption performance did not fit the linear model (Fig. 5a) because it was changing its course after the first $20 \mathrm{~min}$ of the process - the lead uptake did not increase linearly after that time. This means that the phenomenon considered in the current study did not follow pseudo-first order. On the other, the experimental data fitted pseudo-second kinetic model very well (Fig. 5b).

\section{Discussion}

Various authors have demonstrated that lead(II) biosorption reaches low efficiencies at pH below 4.0 (Gong et al. 2005b; Wang and Chen 2006; Raoof et al. 2006; Benaïssa and Elouchdi 2007) so in the recent study only the range from 4.0 to 5.5 with 0.5 increment was tested. Hydrogen cations at high concentrations compete for active binding sites with heavy metal ions. On the other hand, lead precipitation occurs at $\mathrm{pH}$ above 5.5 which inhibits metal recovery by 
Fig. 1 PCA analysis of corrected $\mathrm{q}_{\text {corr }}$ (lead uptake) obtained at different times and initial lead concentrations (scores) under various $\mathrm{pH}$ conditions (loadings) for the first three components; circles indicate correlated loads and scores

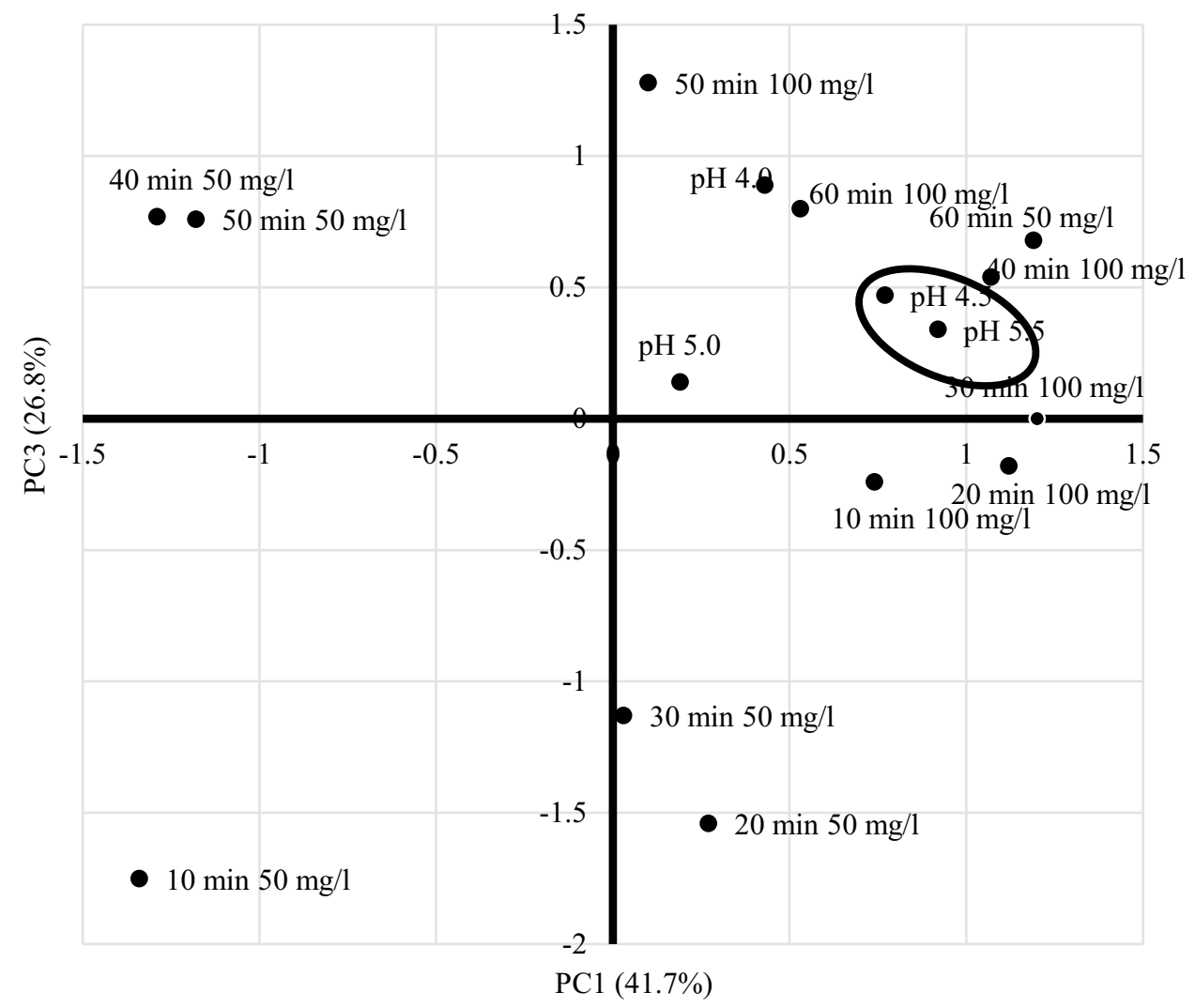

Table 4 Correlations between principal components and original variables

\begin{tabular}{llll}
\hline Variables & PC1 & PC3 & PC2 \\
\hline $10 \mathrm{~min} 50 \mathrm{mg} / \mathrm{l}$ & -1.33762 & -1.7467 & $\mathbf{2 . 1 7 3 9 5 2 3 1}$ \\
$20 \mathrm{~min} 50 \mathrm{mg} / \mathrm{l}$ & 0.2700 & -1.5380 & -1.22019895 \\
$30 \mathrm{~min} 50 \mathrm{mg} / \mathrm{l}$ & -0.0280 & -1.1301 & -1.22599243 \\
$40 \mathrm{~min} 50 \mathrm{mg} / \mathrm{l}$ & -1.2922 & $\mathbf{0 . 7 6 1 0}$ & -0.05009083 \\
$50 \mathrm{~min} 50 \mathrm{mg} / \mathrm{l}$ & -1.1751 & $\mathbf{0 . 7 6 4 5}$ & -1.09187203 \\
$60 \mathrm{~min} 50 \mathrm{mg} / \mathrm{ml}$ & -1.1917 & $\mathbf{0 . 6 7 6 4}$ & -0.71562856 \\
$10 \mathrm{~min} 100 \mathrm{mg} / 1$ & $\mathbf{0 . 7 4 1 1}$ & -0.2390 & 0.24560266 \\
$20 \mathrm{~min} 100 \mathrm{mg} / 1$ & $\mathbf{1 . 1 2 0 2}$ & -0.1837 & -0.12150744 \\
$30 \mathrm{~min} 100 \mathrm{mg} / \mathrm{l}$ & $\mathbf{1 . 1 9 8 6}$ & 0.0028 & -0.08520182 \\
$40 \mathrm{~min} 100 \mathrm{mg} / \mathrm{l}$ & $\mathbf{1 . 0 6 5 4}$ & $\mathbf{0 . 5 3 7 3}$ & $\mathbf{0 . 5 8 6 8 1 2 9 3}$ \\
$50 \mathrm{~min} 100 \mathrm{mg} / \mathrm{l}$ & 0.0998 & $\mathbf{1 . 2 8 2 9}$ & $\mathbf{0 . 8 4 5 0 2 0 0 1}$ \\
$60 \mathrm{~min} 100 \mathrm{mg} / \mathrm{ml}$ & $\mathbf{0 . 5 2 9 6}$ & $\mathbf{0 . 8 0 3 7}$ & $\mathbf{0 . 6 5 9 1 0 4 1 5}$ \\
\hline
\end{tabular}

Values marked in bold indicate significant correlations

the biomass (Xuan et al. 2006; Oluyemi et al. 2012; Samra et al. 2014). Based on the obtained results, $\mathrm{pH} 4.0$ and 4.5 provided conditions for more efficient $\mathrm{Pb}^{2+}$ recovery which might be explained by the fact that only ionic forms of heavy metals are available to the microbial biomass.

Chen and Pan (2005a) demonstrated that lead did not cause significant damage of $A$. platensis cells over 7 days of incubation at metal concentration ranging up to $20 \mathrm{mg} / \mathrm{l}$.
In the current study, higher heavy metal concentration increased chances of "contacting" ions with active binding sites which resulted in enhanced sorption. The adsorption of metal ions by filter paper has not been considered in previous studies where the same procedure of separating biosorbent from test solution was applied (Gong et al. 2005b; Parvathi et al. 2007; Şeker et al. 2008; Solisio et al. 2008). Therefore, it would be needed to revise results and findings reported in cited papers to verify actual efficiencies of lead(II) removal by microbial biomass.

According to the results obtained in PCA the strongest correlation was noted between $\mathrm{pH} 4.5$ and 5.5 (Fig. 1) which might be explained by the fact that at $\mathrm{pH} 5.5$ partial precipitation of lead occurs which means that metal ions are less available to cyanobacteria cells (Akar and Tunali 2006) while the highest metal recovery was obtained at $\mathrm{pH} 4.5$. On the other hand, $\mathrm{pH}$ values 4.0 and 4.5 are the most significant parameters in lead(II) biosorption. That correlation could be explained by the fact that at both lead initial concentrations extending the time of shaking experimental flasks did not improve lead recovery, except for experiments carried out at $100 \mathrm{mg}$ of $\mathrm{Pb}^{2+} / \mathrm{L}$ at $\mathrm{pH} 4.5$ where slight improvement of $\mathrm{q}_{\text {corr }}$ values was noted (Tables 1,2).

Another strong correlation was noted between $\mathrm{pH} 4.0$ and 4.5 (Fig. 1) and it might be explained by the fact that biosorption was the most effective at these two $\mathrm{pH}$ values at lead initial concentrations 50 and $100 \mathrm{mg} / \mathrm{l}$, respectively. 
Fig. 2 Langmuir isotherm of lead(II) sorption by living cells intervals $[\mathrm{pH}=4.5$, lead(II) initial concentration $=100 \mathrm{mg} / \mathrm{l}$, rotary speed $=200 \mathrm{rpm}$ ] of A. platensis at different time

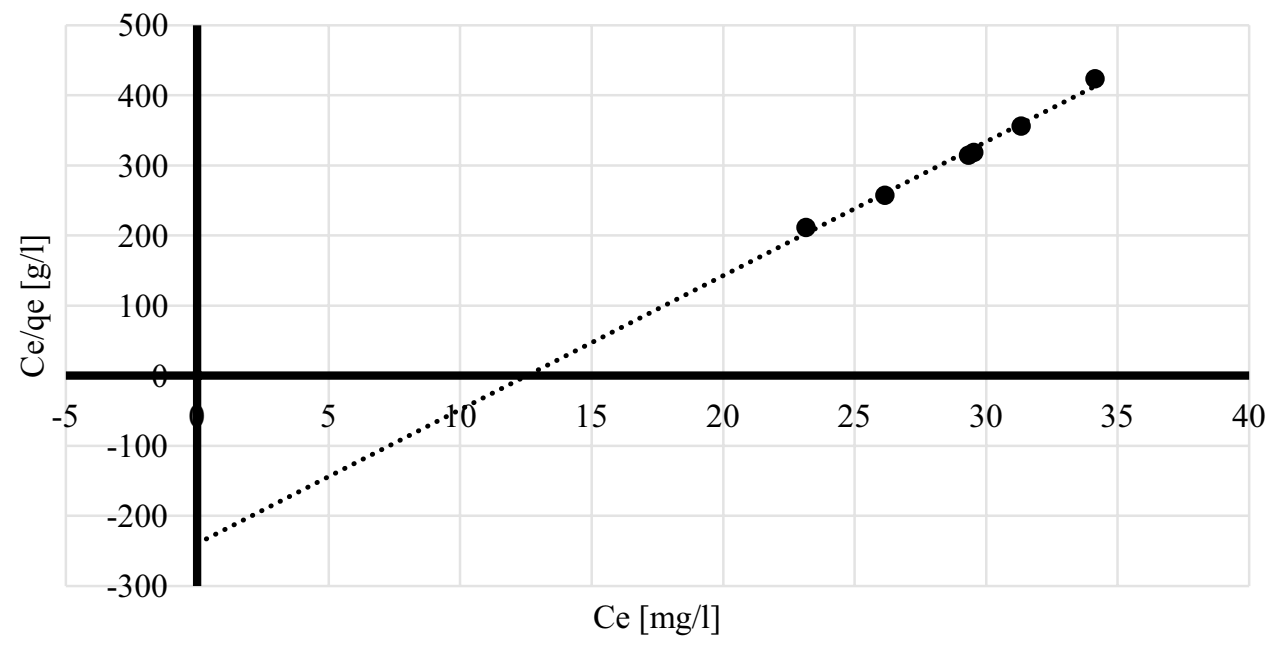

Fig. 3 Freundlich isotherm of lead(II) sorption by living cells of A. platensis at different time intervals $[\mathrm{pH}=4.5$, lead(II) initial concentration $=100 \mathrm{mg} / \mathrm{l}$, rotary speed $=200 \mathrm{rpm}$ ]

Fig. 4 Dubinin-Raduskhevich of lead(II) sorption by living cells of $A$. platensis at different time intervals $[\mathrm{pH}=4.5$, lead(II) initial concentration $=100 \mathrm{mg} / \mathrm{l}$, rotary speed $=200 \mathrm{rpm}$ ]
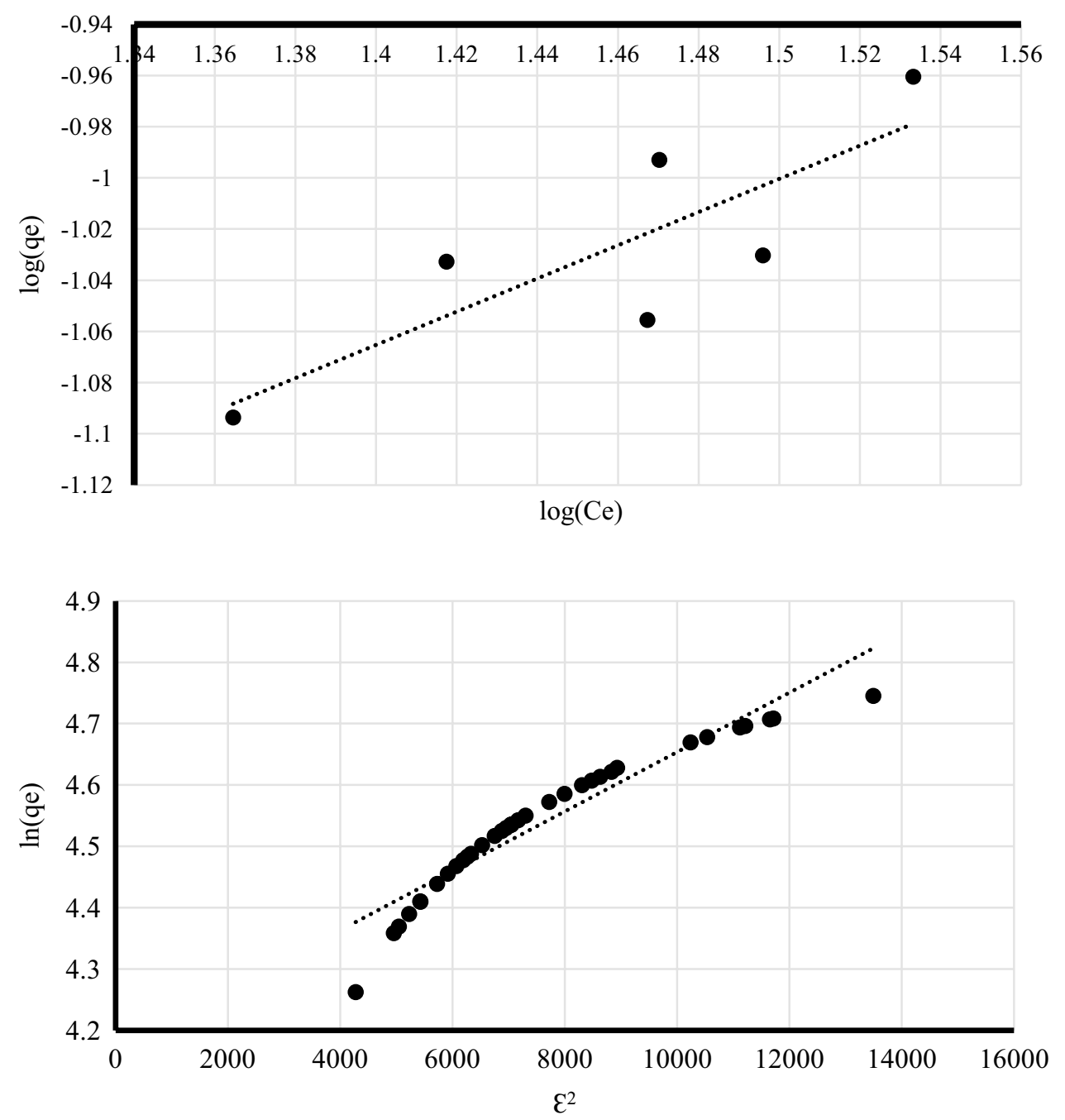

Strong correlation also occurred between $\mathrm{pH} 4.0$ and 5.5 (Table 3). Possible explanation to this phenomenon could be that at those $\mathrm{pH}$ values lead uptake $\left(\mathrm{q}_{\text {corr }}\right)$ was increasing up to 30 or 40 min and it was decreasing afterward. In conclusion, PCA was found useful for analysing biosorption data obtained from preliminary studies. 
Table 5 The summary of sorption isotherms

\begin{tabular}{lll}
\hline Isotherm type & Isotherm constants & $\begin{array}{l}\text { Regression } \\
\text { coefficient } \\
{\left[\mathrm{R}^{2}\right]}\end{array}$ \\
\hline Langmuir & $\mathrm{Q}_{\max }=254.4, \mathrm{~b}=0.020361$ & 0.9896 \\
Freundlich & $\mathrm{K}_{\mathrm{f}}=0.010629, \mathrm{n}=1.541545$ & 0.6854 \\
Dubinin-Radushkevich & $\mathrm{qs}=64.70 \mathrm{mg} / \mathrm{g}, \mathrm{K}_{\mathrm{ad}}=100 \mathrm{~mol}^{2} / \mathrm{J}^{2}$ & 0.9124 \\
Pseudo-first order & $\mathrm{k}_{1}=1.54 / \mathrm{min}$ & 0.3755 \\
Pseudo-second order & $\mathrm{q}_{2}=0.0512 \mathrm{mg} / \mathrm{g}, \mathrm{k}_{2}=0.0088[\mathrm{~min} \cdot \mathrm{g} / \mathrm{mg}]$ & 0.9551 \\
\hline
\end{tabular}

Fig. 5 Pseudo-first (a) and pseudo-second (b) kinetic models of lead(II) sorption by living cells of $A$. platensis at different time intervals $[\mathrm{pH}=4.5$, lead(II) initial concentration $=100 \mathrm{mg} / \mathrm{l}$, rotary speed $=200 \mathrm{rpm}$ ]
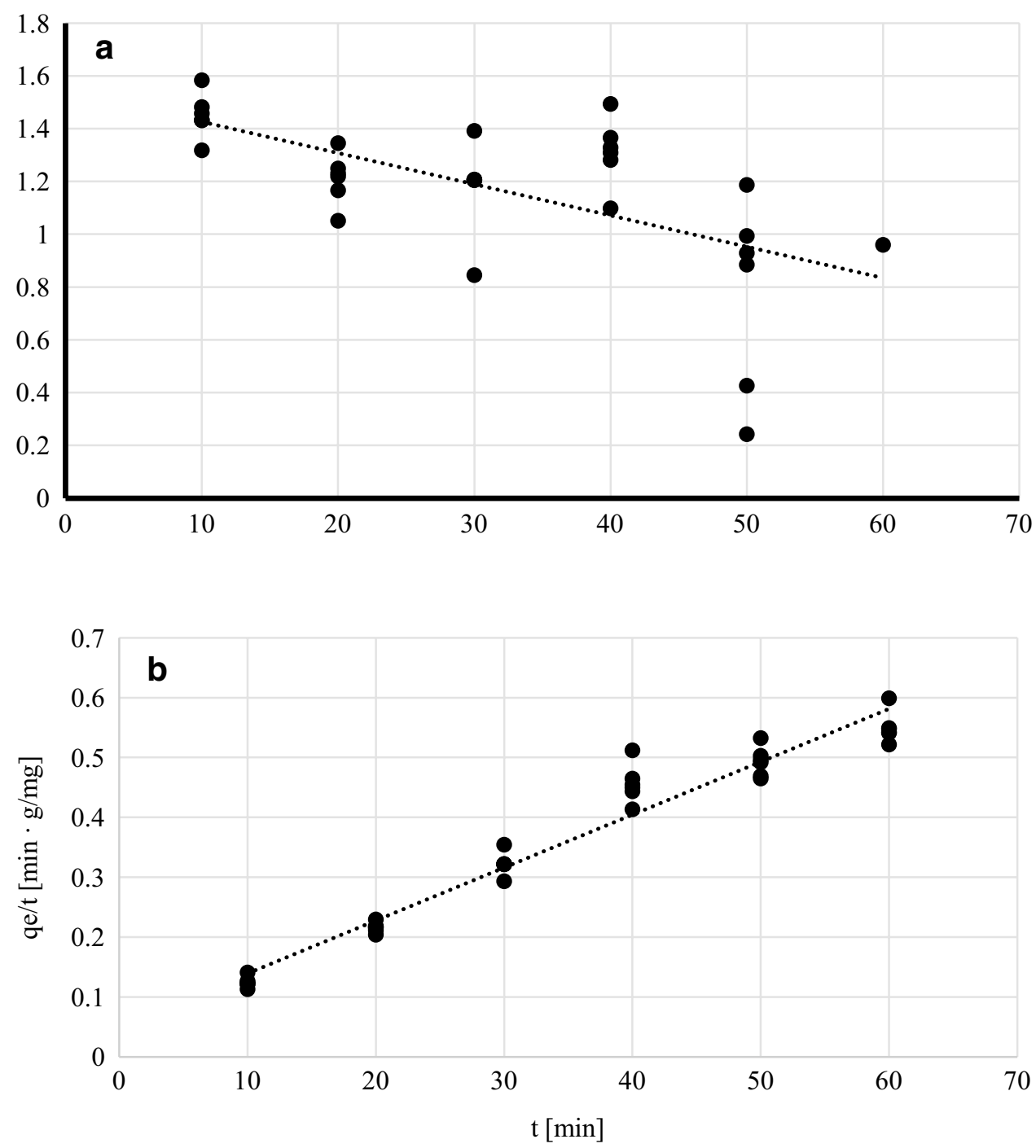

There was a higher regression coefficient obtained for Langmuir isotherm (Table 5) which indicates that the main mechanism responsible for lead(II) recovery was physical absorption. It might be concluded that heavy metal ions were organised in a monolayer (Volesky 2004) but their affinity to cell walls of tested cyanobacterium was relatively low (Table 5) due to the fact that $b$ constant was very low. This might explain why after first 10 min $\mathrm{q}_{\mathrm{corr}}$ values were high and they decreased after another $10 \mathrm{~min}$. On the other hand, relatively high $\mathrm{Q}_{\max }$ value $(254.4 \mathrm{mg} / \mathrm{g}$ of d.m.) indicates that cyanobacterium biomass could be more effective at higher $\mathrm{Pb}^{2+}$ concentrations or remove the metal more effectively after further optimisation. The value of that constant also suggests that there are many binding sites available on the surface of the cyanobacterial cell walls. Moreover, results obtained for Freundlich model indicate that the 
biosorbent surface was not homogenous (Volesky 2004) which is not surprising when complex chemical composition and structure of cell walls are considered (Van Eykelenburg 1978). High material porosity was also confirmed by the data obtained from Dubinin-Raduskhevich model and the value of free sorption energy $\mathrm{E}$, which was higher than 8 (Table 5), confirmed that the biosorption phenomenon performed by living cells of $A$. platensis was based on the chemical sorption (Erhayem et al. 2015). Additionally, the fact that the process follows according to the pseudo-second order confirms that chemical biosorption was very significant mechanism taking place during processes described in the current paper.

The most significant factor influencing lead(II) biosorption by living cells of $A$. platensis is $\mathrm{pH}$ and initial metal concentration, while the influence of the contact time is less significant. Moreover, when filter paper is used for separating biomass from the test solution, it has to be determined how much metal is absorbed by that material or that step should be replaced with other separation techniques (i.e. centrifugation). PCA indicated that $\mathrm{pH} 5.5$ was not significant for lead(II) biosorption under tested conditions and optimum parameters for this process were initial metal concentration $100 \mathrm{mg} / \mathrm{l}, \mathrm{pH} 4.5$ and contact time $60 \mathrm{~min}$, however, equilibrium was reached after $30 \mathrm{~min}$. It seems that physical sorption is the main mechanism of the described processes. Further studies are necessary to investigate the mechanism of $\mathrm{Pb}^{2+}$ biosorption by living cells of $A$. platensis and examine the influence of other factors that have an influence on that phenomenon. Moreover, it should be verified if cyanobacterium cells survive continuous sorption-desorption cycles and how that process could be optimised.

Open Access This article is distributed under the terms of the Creative Commons Attribution 4.0 International License (http://creativecommons.org/licenses/by/4.0/), which permits unrestricted use, distribution, and reproduction in any medium, provided you give appropriate credit to the original author(s) and the source, provide a link to the Creative Commons license, and indicate if changes were made.

\section{References}

Akar T, Tunali S (2006) Biosorption characteristics of Aspergillus flavus biomass for removal of $\mathrm{Pb}$ (II) and $\mathrm{Cu}$ (II) ions from an aqueous solution. Bioresour Technol 97:1780-1787. doi:10.1016/j. biortech.2005.09.009

Al-Degs YS, Abu-El-Halawa R, Abu-Alrub SS (2012) Analyzing adsorption data of erythrosine dye using principal component analysis. Chem Eng J 191:185-194. doi:10.1016/j.cej.2012.03.002

Beaumont R (2012) An introduction to principal component analysis $\&$ factor analysis using SPSS 19 and R (psych package). pp 1-24

Benaïssa H, Elouchdi MA (2007) Removal of copper ions from aqueous solutions by dried sunflower leaves. Chem Eng Process 46:614-622. doi:10.1016/j.cep.2006.08.006
Chen H, Pan S-S (2005a) Bioremediation potential of spirulina: toxicity and biosorption studies of lead. J Zhejiang Univ Sci B 6:171174. doi:10.1631/jzus.2005.B0171

Chen H, Pan S-S (2005b) Bioremediation potential of spirulina: toxicity and biosorption studies of lead. J Zhejiang Univ Sci 6:171174. doi:10.1631/jzus.2005.B0171

Chen B, Liu J, Wang Z et al (2011) Remediation of Pb-resistant bacteria to $\mathrm{Pb}$ polluted soil. J Environ Prot (Irvine Calif) 2:130-141. doi:10.4236/jep.2011.22015

Da Costa AA, De França FP (1998) Short communication: cadmium uptake by Spirulina maxima: toxicity and mechanism. World J Microbiol Biotechnol 14:579-581. doi:10.102 3/A:1008888031994

Dada A, Olalekan A, Olatunya A, Dada O (2012) Langmuir, Freundlich, Temkin and Dubinin-Radushkevich isotherms studies of equilibrium sorption of $\mathrm{Zn} 2+$ unto phosphoric acid modified rice husk. IOSR J Appl Chem 3:38-45. doi:10.9790/5736-0313845

Dai J, Becquer T, Rouiller JH et al (2004) Heavy metal accumulation by two earthworm species and its relationship to total and DTPA-extractable metals in soils. Soil Biol Biochem 36:91-98. doi:10.1016/j.soilbio.2003.09.001

Damstra T (1977) Toxicological properties of lead. Environ Health Perspect 19:297-307. doi:10.1289/ehp.7719297

Duda-Chodak A, Wajda L, Tarko T (2013) The immobilization of arthrospira platensis biomass in different matrices-A practical application for lead biosorption. J Environ Sci Health A Tox Hazard Subst Environ Eng 48:509-517. doi:10.1080/10934529 .2013 .730425

Erhayem M, Al-tohami F, Mohamed R, Ahmida K (2015) Isotherm, kinetic and thermodynamic studies for the sorption of mercury(II) onto activated carbon from Rosmarinus officinalis leaves. Am J Anal Chem 6:1-10. doi:10.4236/ajac.2015.61001

Ghaedi M, Ghaedi AM, Abdi F et al (2014) Principal component analysis-artificial neural network and genetic algorithm optimization for removal of reactive orange 12 by copper sulfide nanoparticlesactivated carbon. J Ind Eng Chem 20:787-795. doi:10.1016/j. jiec.2013.06.008

Gokhale SV, Jyoti KK, Lele SS (2008) Kinetic and equilibrium modeling of chromium(VI) biosorption on fresh and spent Spirulina platensis/Chlorella vulgaris biomass. Bioresour Technol 99:3600 3608. doi:10.1016/j.biortech.2007.07.039

Gong R, Ding Y, Liu H et al (2005a) Lead biosorption and desorption by intact and pretreated spirulina maxima biomass. Chemosphere 58:125-130. doi:10.1016/j.chemosphere.2004.08.055

Gong R, Ding Y, Liu H et al (2005b) Lead biosorption and desorption by intact and pretreated spirulina maxima biomass. Chemosphere 58:125-130. doi:10.1016/j.chemosphere.2004.08.055

Hutson ND, Yang RT (1997) Theoretical basis for the Dubinin-Radushkevitch (D-R) adsorption isotherm equation. Adsorption 3:189195. doi:10.1007/BF01650130

Lodi A, Soletto D, Solisio C, Converti A (2008) Chromium(III) removal by Spirulina platensis biomass. Chem Eng J 136:151155. doi:10.1016/j.cej.2007.03.032

Oluyemi EA, Adeyemi AF, Olabanji IO (2012) Removal of Pb2+ and $\mathrm{Cd} 2+$ ions from wastewaters using palm kernel shell charcoal (PKSC). Res J Eng Appl Sci 1:308-313

Parvathi K, Nagendran R, Nareshkumar R (2007) Lead biosorption onto waste beer yeast by-product, a means to decontaminate effluent generated from battery manufacturing industry. Electron J Biotechnol 10:92-105. doi:10.2225/vol10-issue1-fulltext-13

Raoof B, Kaushik BD, Prasanna R (2006) Formulation of a low-cost medium for mass production of Spirulina. Biomass Bioenergy 30:537-542. doi:10.1016/j.biombioe.2005.09.006

Samra SE, Jaregh B, El-Nokrashy AM, El-Asmy AA (2014) Biosorption of $\mathrm{Pb} 2+$ from natural water using date pits: a 
green chemistry approach. Mod Chem Appl 2:1000131. doi:10.4172/2329-6798.1000131

Şeker A, Shahwan T, Eroğlu AE et al (2008) Equilibrium, thermodynamic and kinetic studies for the biosorption of aqueous lead(II), cadmium(II) and nickel(II) ions on Spirulina platensis. J Hazard Mater 154:973-980. doi:10.1016/j.jhazmat.2007.11.007

Solisio C, Lodi A, Soletto D, Converti A (2008) Cadmium biosorption on Spirulina platensis biomass. Bioresour Technol 99:5933-5937. doi:10.1016/j.biortech.2007.11.002

Van Eykelenburg C (1978) A glucan from the cell wall of the cyanobacterium Spirulina platensis. Antonie Van Leeuwenhoek 44:321-327. doi:10.1007/BF00394309

Vannela R, Verma SK (2006) Co2+, Cu2+, and Zn2 + accumulation by cyanobacterium Spirulina platensis. Biotechnol Prog 22:12821293. doi:10.1021/bp060075s
Volesky B (2004) Equilibrium biosorption performance. Sorption and biosorption. BV-Sorbex Inc, Montreal, pp 103-116

Volesky B, Naja G (2005) Biosorption: application strategies. In: Harrison STL, Rawlings DE, Petersen J (eds) Proc. 16th Biotechnol. Symp. IBS - Compress Co., Cape Town, pp 531-542

Wang J, Chen C (2006) Biosorption of heavy metals by Saccharomyces cerevisiae: a review. Biotechnol Adv 24:427-451. doi:10.1016/j. biotechadv.2006.03.001

Xuan Z, Tang Y, Li X et al (2006) Study on the equilibrium, kinetics and isotherm of biosorption of lead ions onto pretreated chemically modified orange peel. Biochem Eng J 31:160-164. doi:10.1016/j.bej.2006.07.001 